Final article:

Lindgreen, A. (2001), "An exploration of contemporary marketing practices in the New Zealand wine sector: evidence from three cases", International Journal of Wine Business Research, Vol. 13, No. 1, pp. 5-22. (ISSN 0954-7541)

For full article, please contact LindgreenA@ cardiff.ac.uk

\title{
An Exploration of Contemporary Marketing Practices in the New Zealand Wine Sector: Evidence from three cases
}

\author{
Adam Lindgreen, Université catholique de Louvain, Belgium ${ }^{1,2}$,
}

Key words Contemporary marketing practices; New Zealand wine sector; Case studies; Relationship marketing

\begin{abstract}
The purpose of a current research project is to examine whether or not transaction marketing is being employed together with various types of relationship marketing. A classification scheme of contemporary marketing practices (Coviello, Brodie and Munro 1997) is reviewed, and the need to enrich earlier research findings is discussed. A case study methodology for conducting research

1 Correspondence should be addressed to Adam Lindgreen, Unité Marketing, Institut d'Administration et Gestion, Université catholique de Louvain, 1 Place des Doyens, 1348 Louvain-la-Neuve, Belgium. Email lindgreen@mark.ucl.ac.be. Telephone + 32 - 1047 8481. Fax $+32-10478324$.

${ }^{2}$ Thanks to Professor Jacqueline Pels (Universidad Torcuato di Tella) for helping me in the analysis of Corbans Wines. Special thanks go to Professor Rod Brodie at the University of Auckland and Senior Lecturer Ian Crawford at Cranfield University for providing much
\end{abstract}


into the New Zealand wine sector is then considered. The preliminary findings suggest that vineyards increasingly employ a pluralistic approach to marketing combining transaction marketing with relational types of marketing, and that softer sides of marketing are becoming important, such as social bonding, networks and interactions. The findings also give insights into whether or not vineyards are driven by their product or market.

\section{INTRODUCTION}

Sheth and Sisodia (1999) and Brookes, Brodie and Lindgreen (2000) argue that the way marketing is being practiced is changing due to dramatic changes in marketing's context: physical distance, time, markets and competition. The “contemporary marketing practice" (CMP) research group seeks to understand the nature of this change in marketing's context and practice (e.g., Brodie et al. 1997). One of the main findings from the CMP research programme has been that managers are placing a greater emphasis on managing their marketing relationships, both internally with employees and externally with suppliers, customers, and other important markets. Another main finding, however, has been that in many organisations there is a pluralistic approach to marketing and how it is practiced - with relationship marketing being carried out in conjunction with traditional "4Ps" marketing management (i.e., product, price, promotion and place). 
In an effort to clarify and reconcile the various views of marketing, Coviello and her colleagues (e.g., Coviello, Brodie and Munro 1997) have developed a classification scheme that builds upon content analysis of how European and North American schools have defined marketing in the literature. As illustrated in Table 1 and Table 2, the scheme is based upon two themes: relational exchange (with seven dimensions; Table 1) and management activities and processes (with five dimensions; Table 2). Two general marketing perspectives were identified transaction marketing and relationship marketing - and these two marketing perspectives were found to encompass four distinct types of marketing: transaction marketing, database marketing, interaction marketing and network marketing. The scheme does not place distinct boundaries between the four types of marketing, and the different types of marketing are not necessarily independent and mutually exclusive.

Transaction marketing has been seen as the "process of planning and executing the conception, pricing, promotion, and distribution of ideas, goods, and services" (American Association 1985, in Brodie et al. 1997: 383). The 4Ps place strong emphasis on achieving larger market share and bigger profits by attracting new customers (e.g., Hillier 1999). Relationship marketing, on the other hand, seeks not only to develop but also to maintain and enhance longer-term relationships with suppliers, customers and other important markets, as this is believed to provide for a sustained competitive advantage (McKenna 1991). The three types of relationship marketing (Table 1 and Table 2) approach marketing in their own characteristic way. For example, in database marketing the developments in information technology since the mid-1980s have made personalised marketing 
relationships possible, such as personalised letters from Amazon.com (e.g., Blomqvist, Dahl and Haeger 1993; Copulsky and Wolf 1990). In interaction marketing the buyer is involved in the design and development of the product or service, such as individualised Levi's jeans and user-designed greeting cards (Gordon 1998; Magrath and Hardy 1994). Brodie et al. 1997 note that such relationships are based on promises, trust and personal interactions. The third type of marketing, network marketing, involves internal marketing, personalised relationships and strategic alliances (Gummesson 1999).

\section{Setting: New Zealand Wine Sector}

Agribusiness has traditionally embraced transaction marketing (e.g., Barkema 1992; Barry, Sonka and Lajili 1992) but has recently started to turn to relationship marketing, as evidenced by the development of horizontal links and vertical links in the sector (e.g., Hughes 1994; Srivastava, Ziggers and Schrader 1998). It would, therefore, seem that agribusiness would be an appropriate setting for examining the research problems - with transaction marketing and different types of relationship marketing both potentially being present.

New Zealand was not recognised as a serious international wine producer until the 1980s. In 1999, New Zealand's export of wines was worth NZ\$ 125.3 million, which was equal to some nine per cent of the country's total horticultural exports. Britain is the single largest export market for New Zealand wines: In the decade from 1989 to 1999 , exports to Britain increased from less than one million litres to a little more than nine million litres so that this market now generates almost 55 
per cent of the total New Zealand wine export revenues (Wine Institute of New Zealand 1999).

The increase in wine exports to the British market is, in many ways, remarkable: New Zealand was long been guaranteed unrestricted access to the British export market for her agricultural and horticultural commodities, but in 1973 - when Britain joined the European Community - New Zealand exporters were forced to look for alternative markets. Wilson and Benson-Rea (1997) have suggested that the single most important factor behind the success of the wine exports has been the strong relationships between New Zealand vineyards and British importers. Also in the context of the New Zealand wine sector, Beverland and his colleagues have both highlighted the importance of forming strong relationships with distributors and customers and the need for salespeople to be relational orientated (Beverland 1999; Beverland and Baker 1999; Beverland and Bretherton 1999).

\section{Research Problems and Research Questions}

One of the research problems is whether or not transaction marketing is being employed together with various types of relationship marketing. An equally important research problem, however, is whether or not the scheme advocated by Coviello offers an appropriate framework for classifying contemporary marketing practices. The overall research problems are approached by examining the following research questions:

1. What, if any, are the objectives of contemporary marketing programmes? 
2. Are there identifiable marketing activities that, if practised, can be presented as substantive evidence of the practice of transaction marketing and/or relationship marketing?

3. Are there identifiable patterns in the way marketing activities of contemporary marketing programmes are implemented and, if so, is there any evidence of modes of implementation that might be promoted as best practice?

4. How, if at all, are contemporary marketing programmes monitored?

5. In what way(s), if at all, might returns on contemporary marketing programmes be measured?

6. What, if any, are the characteristics of strong buyer-seller relationships?

\section{METHODOLOGY}

The case study method was considered the most suitable research strategy. Unlike an experiment where a phenomenon is deliberately divorced from its context so that the researcher's attention can be focused on only a few variables, in this research it was not possible to distinguish the phenomenon of contemporary marketing practices from the context in which it was being studied. This meant that a holistic perspective on contemporary marketing practices should be taken so that all of the potentially rich and meaningful characteristics of a marketing programme could be kept intact; and these characteristics, which impinged on the behaviour of interest and which were not pre-selected, were observed over time (Lindgreen and Crawford 1999; Yin 1994). There was also strong epistemological justification for using the case study method since the aim was to gain an understanding of a contemporary phenomenon that is both complex and dynamic (e.g., Boing 1994; Lewin and Johnston 1997). 
Table 1. Types of marketing classified by relational exchange dimensions

\begin{tabular}{|c|c|c|c|c|}
\hline & \multirow{2}{*}{$\begin{array}{l}\text { Transactional perspective } \\
\text { Type: transaction marketing }\end{array}$} & \multicolumn{3}{|c|}{ Relational perspective } \\
\hline & & Type: database marketing & Type: interaction marketing & Type: network marketing \\
\hline Focus & Economic transaction & Information and economic transaction & $\begin{array}{l}\text { Interactive relationships between a } \\
\text { buyer and seller }\end{array}$ & $\begin{array}{l}\text { Connected relationships between } \\
\text { firms }\end{array}$ \\
\hline Parties involved & $\begin{array}{l}\text { A firm and buyers in the general } \\
\text { market }\end{array}$ & $\begin{array}{l}\text { A firm and buyers in a specific target } \\
\text { market }\end{array}$ & Individual sellers and buyers (a dyad) & Sellers, buyers, and other firms \\
\hline Communication pattern & Firm to market & Firm to individual & $\begin{array}{l}\text { Individuals "with" individuals (across } \\
\text { organisations) }\end{array}$ & $\begin{array}{l}\text { Firms with firms (involving } \\
\text { individuals) }\end{array}$ \\
\hline Type of contact & Arms-length, impersonal & Personalised (yet distant) & $\begin{array}{l}\text { Face-to-face, interpersonal (close, } \\
\text { based on commitment, trust, and co- } \\
\text { operation) }\end{array}$ & $\begin{array}{l}\text { Impersonal - interpersonal (ranging } \\
\text { from distant to close) }\end{array}$ \\
\hline Duration & Discrete (yet perhaps over time) & Discrete and over time & $\begin{array}{l}\text { Continuous (ongoing and mutually } \\
\text { adaptive, may be short or long term) }\end{array}$ & $\begin{array}{l}\text { Continuous (stable yet dynamic, may } \\
\text { be short or long term) }\end{array}$ \\
\hline Formality & Formal & $\begin{array}{l}\text { Formal (yet personalised via } \\
\text { technology) }\end{array}$ & $\begin{array}{l}\text { Formal and informal (that is, both a } \\
\text { business and social level) }\end{array}$ & $\begin{array}{l}\text { Formal and informal (that is, both a } \\
\text { business and social level) }\end{array}$ \\
\hline Balance of power & Active seller - passive buyers & Active seller - less passive buyers & $\begin{array}{l}\text { Seller and buyer mutually active and } \\
\text { adaptive (interdependent and } \\
\text { reciprocal) }\end{array}$ & All firms active and adaptive \\
\hline
\end{tabular}

Source: Coviello, N. E., Brodie, R. J. And Munro, H. J. (1997), "Understanding contemporary marketing: development of a classification scheme", Journal of Marketing Management, Vol. 13, No. 6, pp. 501-552, p. 387. 
Table 2. Types of marketing classified by managerial dimensions

\begin{tabular}{|c|c|c|c|c|}
\hline & \multirow{2}{*}{$\begin{array}{l}\text { Transactional perspective } \\
\text { Type: transaction marketing }\end{array}$} & \multicolumn{3}{|c|}{ Relational perspective } \\
\hline & & Type: database marketing & Type: interaction marketing & Type: network marketing \\
\hline Managerial intent & $\begin{array}{l}\text { Customer attraction (to satisfy the } \\
\text { customer at a profit) }\end{array}$ & $\begin{array}{l}\text { Customer retention (to satisfy the } \\
\text { customer, increase profit, and attain } \\
\text { other objectives, such as increased } \\
\text { loyalty, decreased customer risk) }\end{array}$ & $\begin{array}{l}\text { Interaction (to establish, develop, and } \\
\text { facilitate a co/operative relationship } \\
\text { for mutual benefit) }\end{array}$ & $\begin{array}{l}\text { Co-ordination (interaction between } \\
\text { sellers, buyers, and other parties } \\
\text { across multiple firms for mutual } \\
\text { benefit, resource exchange, market } \\
\text { access) }\end{array}$ \\
\hline Decision focus & Product or brand & $\begin{array}{l}\text { Product/brand and customers (in a } \\
\text { targeted market) }\end{array}$ & Relationships between individuals & $\begin{array}{l}\text { Connected relationships between } \\
\text { firms (in a network) }\end{array}$ \\
\hline Managerial investment & $\begin{array}{l}\text { Internal marketing assets (focusing on } \\
\text { product/service, price, distribution, } \\
\text { promotion capabilities) }\end{array}$ & $\begin{array}{l}\text { Internal marketing assets } \\
\text { (emphasising communication, } \\
\text { information, and technology } \\
\text { capabilities) }\end{array}$ & $\begin{array}{l}\text { External market assets (focusing on } \\
\text { establishing and developing a } \\
\text { relationship with another individual) }\end{array}$ & $\begin{array}{l}\text { External market assets (focusing on } \\
\text { developing the firms position in a } \\
\text { network of firms) }\end{array}$ \\
\hline Managerial level & $\begin{array}{l}\text { Functional marketers (that is, sales } \\
\text { manager, product development } \\
\text { manager) }\end{array}$ & $\begin{array}{l}\text { Specialist marketers (that is, customer } \\
\text { service manager, loyalty manager) }\end{array}$ & $\begin{array}{l}\text { Managers from across functions and } \\
\text { levels in the firm }\end{array}$ & General manager \\
\hline Time frame & Short/term & Longer-term & Short- or long-term & Short- or long-term \\
\hline
\end{tabular}

Source: Coviello, N. E., Brodie, R. J. and Munro, H. J. (1997), “Understanding contemporary marketing: development of a classification scheme”, Journal of Marketing Management, Vol. 13, No. 6, pp. 501-552, p. 388. 


\section{Theory Development from Case Study Data}

Design of Case Study The case study was multiple and embedded focusing on the marketing programmes of New Zealand vineyards and British importers. The case study also examined the marketing philosophy of senior marketing directors with the vineyards and the importers. (As we shall see shortly, the case study included other potentially important players by networking from the vineyards and the importers.)

Selecting Cases There are currently 377 vineyards in New Zealand, categorised after their annual sales volume with three categories in all. The criteria for the vineyards that were included in the study were as follows:

- The vineyards should be of different sizes.

- It should not be too difficult to get to a particular vineyard (geographical proximity; see Gummesson 1991).

- The vineyards should export to Britain.

In a meeting with the Wine Institute of New Zealand, five Category 1 vineyards, two Category 2 vineyards and two Category 3 vineyards were identified (Table 3). For all of the vineyards, the research sought to gather information both upstream and downstream, including from the growers, distributors, importers and sellers. The research also included the Wine Institute of New Zealand as a 'background case study' - the aim of the organisation is to safeguard the interests of the wine sector in New Zealand. 
Table 3. New Zealand vineyards included in the case study

\begin{tabular}{lll}
\hline Category $\mathbf{1}$ & Category 2 & Category 3 \\
\hline Goldwater Estate & Babich Wines & Corbans Wines \\
Kumeu River Wines & Hunter's Wines & Villa Maria Estate \\
Te Mata Estate Winery & & \\
Trinity Hill & & \\
Waiheke Vineyards & \\
\hline
\end{tabular}

Crafting Instruments and Protocols Most of the case study data came from qualitative in-depth, face-to-face interviews, which usually are considered as the most valuable source of information when investigating the underlying meaning of complex phenomena and processes (Dey 1993; Lincoln and Guba 1985). An interview protocol (building upon Coviello's two schemes and the research questions) was crafted because multiple case studies are prone to loss of focus.

Analysing the Data The analysis of interview data was carried out in two stages: within-case analysis, involving write-ups for each case, and cross-case analysis, involving searches for cross-case patterns. In the within-case analysis, each case was analysed in an interactive process (Miles and Huberman 1994) consisting of four main components, as illustrated in Figure 1. Overall, the volume of data was condensed through coding and memoing (see shortly) as well as in the activities of finding themes, clusters and patterns. In order not to reduce data so much that significant information was lost, the research was not stripped from its context (Punch 1998). In general, the research sought to back up interpretations through triangulation with any claim supported with multiple sources of evidence (Yin 1994). 


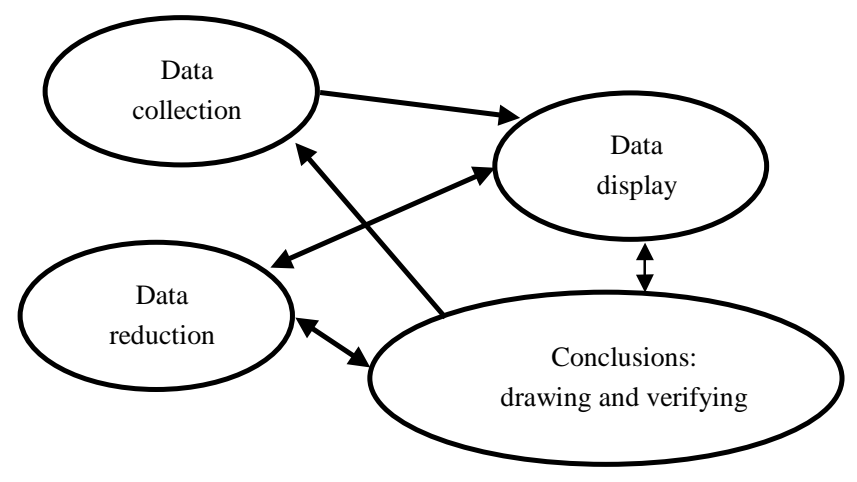

\section{Figure 1. Components of data analysis: interactive model}

Source: Miles, B. and Huberman, A. M. (1994), Qualitative Data Analysis: An Expanded Sourcebook, 2nd edition, Sage Publications, Thousand Oaks, California, p. 12.

With regard to coding, labels were put against pieces of the data (Glaser 1978; Miles and Huberman 1994; Punch 1998). That is, the coding consisted of summarising the data by pulling together themes and identifying patterns by employing a pre-specified coding scheme. For example, a vineyard's objectives in terms of the marketing programme could be themed in terms of customer attraction; customer retention; product driven; market driven; transactions; and/or relationships. In the cross-case analysis, one method was to look for inter-group differences in important dimensions. Another one was to list similarities and differences between sets of cases. Yet a third method was to divide the data by their source and then to establish whether the sources resulted in the same pattern.

A common concern has been that case studies provide little basis for generalising the results (Yin 1994). To judge whether or not the case study findings from one contextual setting can be transferred another contextual setting, the research sought to describe each setting as thickly as possible (Punch 1998). Moreover, the level of abstraction of the concepts in the data analysis was at such a level to allow their application to other contextual settings (e.g., Glaser and Strauss 1967; 
Yin 1994). Researchers have also often been worried about the reliability of the case study findings. Although there are no standardised methodological rules and techniques for conducting case studies, there are certain methodological guidelines and analysis procedures (Creswell 1994; Eisenhardt 1989; Flick 1998; Miles and Huberman 1994; Tesch 1990; Yin 1994). The design tests and case study tactics, which were employed in the research, have been listed in Table 4.

Table 4. Design tests and case study tactics that were employed

\begin{tabular}{|c|c|c|}
\hline Design test & $\begin{array}{l}\text { Theoretical explanation of the } \\
\text { construct }\end{array}$ & $\begin{array}{l}\text { Case study tactics that were } \\
\text { employed }\end{array}$ \\
\hline Construct validity & $\begin{array}{l}\text { Construct validity is to secure that correct } \\
\text { operational measures have been established } \\
\text { for the concepts that are being studied (Yin } \\
\text { 1994) }\end{array}$ & $\begin{array}{l}\text { - Multiple sources of evidence } \\
\text { - } \quad \text { Interview respondents reviewing the draft } \\
\text { of each case study report }\end{array}$ \\
\hline Internal validity & $\begin{array}{l}\text { Internal validity is to make sure that a causal } \\
\text { relationship - certain conditions lead to other } \\
\text { conditions - has been established. Internal } \\
\text { validity is a concern for explanatory or causal } \\
\text { case studies but not for exploratory or } \\
\text { descriptive case studies, which do not attempt } \\
\text { to make causal statements (Yin 1994) }\end{array}$ & $\begin{array}{l}\text { - } \quad \text { Pattern matching } \\
\text { - } \quad \text { Rival explanation as patterns } \\
\text { - } \quad \text { Explanation building } \\
\text { - Time series analysis }\end{array}$ \\
\hline External validity & $\begin{array}{l}\text { External validity is to prove that the domain to } \\
\text { which a case study's findings belong can be } \\
\text { generalised (Yin 1994) }\end{array}$ & $\begin{array}{l}\text { - } \quad \text { Specification of the population of interest } \\
\text { - } \quad \text { Replication logic in multiple case studies }\end{array}$ \\
\hline Reliability & $\begin{array}{l}\text { Reliability involves demonstrating that the } \\
\text { findings from a case study can be repeated if } \\
\text { the case study procedures are followed (Yin } \\
\text { 1994) }\end{array}$ & $\begin{array}{l}\text { - Interview protocol } \\
\text { - Clearly conceptualised constructs } \\
\text { - Multiple indicators } \\
\text { - Execution of pilot tests } \\
\text { - Case study data base }\end{array}$ \\
\hline
\end{tabular}

\section{PRELIMINARY FINDINGS}

\section{First Case Study: Contemporary Marketing Practices}

Corbans Wines ${ }^{3}$ is a 270 -hectare vineyard in New Zealand that exports to 18 international markets including Britain, where it works with Caxton Tower, the largest importer of New World wines into Britain. In the mid-1990s, Caxton 
Tower had increased considerably in size and, as a result, its business procedures became more complexed. At the same time, Caxton Tower still worked on a short-term basis and its business relationships were only supported with limited communications. There had also been many shifts among senior management/marketing executives within Caxton Tower. The succession of CEOs, with their diverse perceptions of the market place and the necessary guidelines, affected the contextual change:

\footnotetext{
"We are now on to the fourth CEO change in eight years ... The CEO introduces culture, structure into the organisation and often personalities in people that have a major impact, positive or negative, on the two companies." (Export manager, Corbans Wines)
}

How did Corbans Wines perceive the environment? First, the vineyard recognised the opportunity of growth in the international wine market, particularly in the British wine market, and invested significant capital to improve its operations. Second, Corbans Wines looked in details at the different avenues it could pursue. Although the vineyard sells its wines in a number of overseas markets, it believes that the British market will remain the single most important market. In addition to that, the vineyard does not have the resources to create a strong brand and, as a result, its strategy has been to reach the consumers through the large retailers. Third, Caxton Tower is one of the largest wine importers in Britain and is - the vineyard reasons - a better match to the retailers. On the other hand, Corbans Wines saw that at that time the business relationship was a mismatch believing that business processes were both ineffective and unstable:

\footnotetext{
${ }^{3}$ Montana Vineyards purchased Corbans Wines in 2000 (after the research was carried out).
} 
"[The] manner [in] which we worked with [Caxton Tower] was quite unstructured, unsystematic, probably quite ineffective and, ultimately, it meant that we were building a business around a relationship that had the potential to be unsustainable and unstable." (Export manager, Corbans Wines)

However, Corbans Wines eventually decided not to look for an alternative importer because it estimated that it would be set back if it changed its distribution system. In the mid-1990s, the vineyard, therefore, first discussed the possibilities of appointing Caxton Tower as its official British importer. This resulted in a number of changes in the management style at the importer:

\begin{abstract}
"We have been able to be constructive and frank on both sides, to identify what the issues are and to verbalise and table those issues and to ensure that the other side clearly understands what ... expectations for a resolution of the problem are. There has been significant management change in this UK business." (Export manager, Corbans Wines)
\end{abstract}

From the talks it was agreed that both parties would invest in the development of a longer in-depth relationship. Then Corbans Wines set up guidelines that would support its new offer proposition to Caxton Tower. Overall, the guidelines aim at managing the business partnership between the two entities:

\footnotetext{
"Where our business is at the moment is right at the other end of the scale and we are implementing a whole bunch of systems and guidelines into our partnerships to ensure that they do operate effectively and both sides have a clear understanding of the mutual objectives and the obligations that each party has to the other. We are setting up a structure in a way of measuring how well we are performing against those guidelines." (Export manager, Corbans Wines)
} 
According to the guidelines, Caxton Tower will manage the marketing and trading activities in Britain, including the relationships with the British retailers, whereas Corbans Wines will agree that the whole production and marketing of wines is controlled using a 36-month plan. In setting up the set of guidelines, Corbans Wines will meet with Caxton Tower and go through all of the aspects and agreeing with the importer on what is meant and what each party has to accomplish. Throughout the whole programme, meetings will take place between the two business entities. The result of the changes will be a match between the vineyard's offer proposition and the importer's need structure.

\section{Second Case Study: A Closed Network}

The general manager of a New Zealand vineyard (name of vineyard withhold for confidentiality reasons) argued that his network has been the single most important factor in the success of the vineyard:

\footnotetext{
"I don't think that our marketing is particularly sophisticated or clever ... The key feature of ours is that we are in networks ... I would switch on the network [when trying to locate a new distributor]. We have found that we virtually don't have to move outside of the networks that we are in." (General manager; name of vineyard withhold for confidentiality reasons)
}

The general manager first served his apprenticeship with Firm A before buying a Firm B, a chain of specialist wine shops in London. At the same time, he became part of a network consisting of similar young people who later went on to senior positions in the wine trade. The value of the network has been evident: 
"Because I knew everybody in the English wine trade, it was not a matter of me finding someone to sell it. I was just dealing with friends. When I walked in they did not just say: 'oh, New Zealand wine, forget it'." (General manager; name of vineyard withhold for confidentiality reasons)

The vineyard does not move outside the network. For example, when it wants to develop a new wine market it will ask its current importers to signal to their colleagues in the new wine market that the vineyard is available for distribution. A formal interview and evaluation process will then take place during which the vineyard will confer with the existing importers:

\footnotetext{
"We have found that we virtually do not have to move outside of the networks that we are in. That is fine because you know where all your money is going and whether you are going to get paid or not and how your goods are going to be sold and presented and all the things that are important. It is the easiest way to do it when you are a small player based in New Zealand." (General manager; name of vineyard withhold for confidentiality reasons)
}

With regard to the British wine market, the vineyard decided to let Firm $\mathrm{C}$ distribute its wines. One reason was that the firm is widely known within the British wine trade. But the single most important reason why the vineyard chose this particular importer was that the general manager had worked in the company back in the 1960s and that he has been close friends with the importer ever since, as evidenced in the following text unit.

"I worked for the [Firm C] in [the 1960s] and we are close friends ... We are all in bed together, and we are throughout the world." (General manager; name of vineyard withhold for confidentiality reasons) 


\section{Third Case Study: Product Driven}

The chief winemaker at Babich Wines explained that the vineyard's wine production has gone (and is going) through three phases. Originally, Babich Wines concentrated on growing good grapes and producing generic wines of good quality for the New Zealand wine shopper:

"[Until] probably fifteen years ago ... if you had good wine you were successful. It did not matter about the label." (Chief winemaker, Babich Wines)

Then, over the three-year period 1997-1999, Babich Wines started focusing on producing wines of the best quality for the New Zealand wine shopper by growing grapes of premium quality. The chief winemaker explained that the approach in the first and second phases of the programme was product driven. For example, in order to produce the quantities of premium grapes that were necessary Babich Wines bought a controlling interest in an existing vineyard in Hawke's Bay. This vineyard was later expanded with another significant vineyard, Marlborough, so that Babich Wines now owns some 70 per cent of its vineyard production:

"[If] you are a company our size, you have to have good quality ... It is very pivotal to this company and that is why we own 70 per cent of our vineyard productions. And we put a lot of effort into working with our vineyard managers and we have a consultant. And we are really committed to premium quality grapes. It does not matter how smart winemaker you are. If you do not have good quality grapes, you cannot make great wine." (Chief winemaker, Babich Wines) 
The vineyard faced a number of challenges during the second phase of the programme - one of the more serious ones was that until this time the management team had no formal training:

\footnotetext{
"[That] was quite a difficult transition ... You have an organisation where the owners and really the people who make the final decisions have only ever worked here. They do not have any formal training ... That process is quite a change in thinking and attitude for the owners." (Babich Wines)
}

Because of that, a chief winemaker was hired; this person was also made responsible for export development. Babich Wines also employed a wine consultant from outside the winery.

Over the next years, Babich Wines will implement the third phase of the transformation, the aim of which is to produce premium wines that are competitive on the world market:

\footnotetext{
"We have an approach that we will make it internationally competitive. We recognise that we operate in a global wine market, not a New Zealand wine market and that is an important change." (Babich Wines)
}

\section{CONCLUSIONS}

Although only preliminary, the findings seem to suggest a number of interesting points. For example, vineyards are increasingly giving up a pure transactional marketing approach and, instead, supplement transaction marketing with more relational marketing activities thus applying a pluralistic approach to marketing. When a vineyard wants to move from transaction marketing to relationship 
marketing it is critical, however, that it understands that this will imply that the vineyard is ready to undergo radical changes in terms of how business is being conducted. Thus, when analysing activities, it will mean moving from a functional to a process approach and, when evaluating performance, it will require moving from a market share to a customer share criterion.

Some researchers have argued that the market should drive organisations that have embarked upon more relational marketing activities (e.g., Capon and Glazer 1987; Glazer 1991). Again, and in accordance with the pluralistic approach to marketing, the research finding that the product drives vineyards - at least to some extent - is in contrast to Capon and Glazer (1987) and Glazer (1991) but supports what has recently been theoretically proposed by Baker and Sinkula (1999) and Dutta, Narasimhan and Rajiv (1999).

The research findings also suggest that the "softer" sides of marketing are becoming increasingly important, e.g. social bonding as in relationships, networks and interactions, and that these softer sides have possible commercial payoffs for both the buyer and the seller. For example, customer satisfaction may translate into higher customer retention and increased shareholder value. Indeed, and evidenced in the case on a closed network, social bonding may lead to behavioural outcomes and increased customer lifetime value. It is proposed to test further this relationship between the softer sides of marketing and the commercial payoffs (Figure 2). 


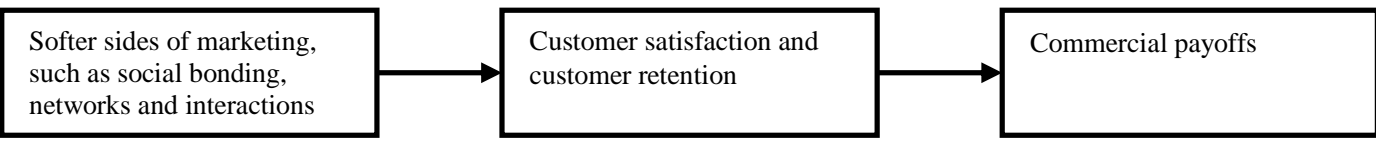

Figure 2. Relationship between softer sides of marketing, customer satisfaction, customer retention and commercial payoffs

The New Zealand-British wine sector is proposed as an appropriate research setting. There are many independent vineyards with only few elements of vertical integration. Because most of the vineyards carry only a small number of wine labels, their relationships with British importers are potentially important enough for the research issue to be meaningful. Restricting the sample to this homogeneous population, extraneous sources of variation are minimised. The relatively large number of vineyards and extreme competitive pressures from other producing countries, such as Australia, the US and Chile, increase the likelihood of there being large variance to be explained.

\section{REFERENCES}

Baker, W. E. and Sinkula, J. M. (1999), "The synergistic effect of market orientation and learning orientation on organizational performance", Journal of the Academy of Marketing Science, Vol. 27, No. 4, pp. 411-427.

Barkema, A. (1992), "Reaching consumers in the twenty-first century: the short way around the barn", American Journal of Agricultural Economics, Vol. 74, pp. 1126-1131.

Barry, P. J., Sonka, S. T. and Lajili, K. (1992), "Vertical coordination, financial structure, and the changing theory of the firm", American Journal of Agricultural Economics, Vol. 74, pp. 1219-1225.

Beverland, M. (1999), "Are salespeople relationship oriented? (And do they need to be?) A study based on the New Zealand wine industry", International Journal of Wine Marketing, Vol. 11, No. 1, pp. 47-64.

Beverland, M. B. and Baker, B. (1999), "Small business strategy in the New Zealand wine industry", Australian and New Zealand Wine Industry Journal, Vol. 14, No. 2, pp. 75-81.

Beverland, M. B. and Bretherton, P. B. (1999), "The role of salespeople in creating relationships", in Manrai, A. K. and Meadow, H. L. (Eds.), World 
Marketing Congress on Global Perspectives in Marketing for the 21st Century, Vol. 9, pp. 338-339.

Blomqvist, R., Dahl, J. and Haeger, T. (1993), Relationsmarknadsföring: Strategi och metod i servicekonkurrens, IHM, Gothenburg.

Boing, H. (1994), "The role of a salesperson within a long term buyer-supplier relationship in the industrial market", in Sheth, J. N. and Parvatiyar, A. (Eds.), 1994 Research Conference Proceedings, Relationship Marketing: Relationship Marketing: Theory, Methods, and Applications, Center for Relationship Marketing, Emory University, Atlanta, Georgia.

Brodie, R. J., Coviello, N. E., Brookes, R. W. and Little, V. (1997), "Towards a paradigm shift in marketing? An examination of current marketing practices", Journal of Marketing Management, Vol. 13, No. 5, pp. 383-406.

Brookes, R. W., Brodie, R. J. and Lindgreen, A. (2000), "Contemporary marketing practice: understanding the trend towards the increased focus of financial accountability and value management", invited paper in Gummesson, E., Liljegren, G. and Feurst, O. (Eds.), Proceedings of the 8th International Colloquium in Relationship Marketing: Return on Relationships, 7-9 December, Stockholm University, Stockholm.

Capon, N. and Glazer, R. (1987), "Marketing and technology: a strategic coalignment", Journal of Marketing, Vol. 51, No. 3, pp. 1-14.

Copulsky, J. R. and Wolf, M. J. (1990), "Relationship marketing: positioning for the future", The Journal of Business Strategy, Vol. 11, No. 4, pp. 16-20.

Coviello, N. E., Brodie, R. J. and Munro, H. J. (1997), "Understanding contemporary marketing: development of a classification scheme", Journal of Marketing Management, Vol. 13, No. 6, pp. 501-22.

Creswell, J. W. (1994), Research Design: Qualitative and Quantitative Approaches, Sage Publications, Thousand Oaks, California.

Dey, I. (1993), Qualitative Data Analysis: A User-friendly Guide for Social Scientists, Routledge, London.

Dutta, S., Narasimhan, O. and Rajiv, S. (1999), "Success in high-technology markets: is marketing capability critical", Marketing Science, Vol. 18, No. 4, pp. 547-568.

Eisenhardt, K. M. (1989), "Building theories from case study research" Academy of Management Review, Vol. 14, No. 4, pp. 532-550.

Flick, U. (1998), An Introduction to Qualitative Research, Sage Publications, London.

Glaser, B. (1978), Theoretical Sensitivity, Sociology Press, Mill Valley, California.

Glaser, B. and Strauss, A. (1967), The Discovery of Grounded Theory: Strategies for Qualitative Research, Aldine, New York.

Glazer, R. (1991), "Marketing in an information-intensive environment: strategic implications of knowledge as an asset", Journal of Marketing, Vol. 55, No. 4, pp. 1-19.

Gordon, I. (1998), Relationship Marketing: New Strategies, Techniques and Technologies to Win the Customers You Want and Keep Them Forever, John Wiley \& Sons, Toronto.

Gummesson, E. (1991), Qualitative Methods in Management Research, Sage Publications, Newbury Park, California.

Gummesson, E. (1999), Total Relationship Marketing: From the 4Ps - product, price, promotion, place - of traditional marketing management to the 30Rs - 
the thirty relationships - of the new marketing paradigm, ButterworthHeinemann, Oxford.

Hillier, T. (1999), "Market share matters", Marketing Business, May, pp. 18-19.

Holmlund, M. (1997), Perceived Quality in Business Relationships, Ekonomi och Samhälle No. 66, Swedish School of Economics and Business Administration, Helsingfors.

Hughes, D. (Ed.) (1994), Breaking With Tradition: Building Partnerships \& Alliances in the European Food Industry, Wye College Press, Wye.

Lewin, J. E. and Johnston, W. J. (1997), "Relationship marketing theory in practice: a case study", Journal of Business Research, Vol. 39, No. 1, pp. 2331.

Lincoln, Y. S. and Guba, E. (1985), Naturalistic Inquiry, Sage Publications, Beverly Hills, California.

Lindgreen, A. and Crawford, I. (1999), "Implementing, monitoring and measuring a programme of relationship marketing", Marketing Intelligence \& Planning, Vol. 17, No. 5, pp. 231-239.

Magrath, A. J. and Hardy, K. G. (1994), "Building customer partnerships", Business Horizons, Vol. 37, No. 1, pp. 24-28.

McKenna, R. (1991), Relationship Marketing: Own the market through strategic customer relationships, Century Business, London.

Miles, B. and Huberman, A. M. (1994), Qualitative Data Analysis: An Expanded Sourcebook, 2nd ed., Sage Publications, Thousand Oaks, California.

Patton, M. Q. (1990), Qualitative Evaluation and Research Methods, Sage Publications, Newbury Park, California.

Punch, K. F. (1998), Introduction to Social Research: Quantitative and Qualitative Approaches, Sage Publications, Thousand Oaks, California.

Sheth, J. N., and Sisodia, R. S. (1999), "Revisiting marketing's generalisations", Journal of Academy of Marketing Science, Vol. 27, No. 1, pp. 71-87.

Srivastava, R., Ziggers, G.-W. and Schrader, L. (1998), "Vertical coordination in the swine industry: a multi-country study", in Ziggers, G. W., Trienekens, J. H. and Zuurbier, P. J. P. (Eds.), Proceedings of the 3rd International Conference on Chain Management in Agribusiness and the Food Industry, Wageningen Agricultural University \& The Foundation for Agri-Chain Competence, Wageningen, pp. 269-280.

Tesch, R. (1990), Qualitative Research: Analysis Types and Software Tools, The Falmer Press, New York.

Wilson, H. and Benson-Rea, M. (1997), "Coopers Creek and the New Zealand wine industry", in Johnson, G. and Scholes, K. (Eds.), Exploring Corporate Strategy: Text and Cases, 4th ed., Prentice Hall Europe, London, pp. 691-702.

Wine Institute of New Zealand (1999) Annual Report: Year End June 1999, Auckland.

Yin, R. K. (1994), Case Study Research: Design and Methods, 2nd ed., Sage Publications, Thousand Oaks, California.

\section{Assistant Professor Adam Lindgreen, PhD}

After graduating in Chemistry, Engineering and Physics, Adam Lindgreen finished first a Master of Science in Food Science/Food Technology at the Technical University of Denmark and then a Master of Business Administration at the University of Leicester in England; after which he worked as a consultant for 
Andersen Consulting in Denmark and Norway. He then completed a Doctorate in Marketing at Cranfield University. He is now with Université catholique de Louvain in Belgium. Adam Lindgreen is particularly interested in customer relationship management, relationship management and relationship quality; agribusiness and the food and wine sectors; and e-business. 